\title{
Nurdin Abdullah Capacity in Utilizing Symbolic Capital to Achieve Power
}

\author{
Muhtar Haboddin ${ }^{1}$, Rizqi Bachtiar ${ }^{2}$ \\ \{muhtar_haboddin@ub.ac.id ${ }^{1}$,rizqi.bachtiar@ub.ac.id²\} \\ Universitas Brawijaya, Indonesia ${ }^{1,2}$
}

\begin{abstract}
This article focuses on the capacity of the traditional elite in optimizing resources to win in the local election of Indonesia. In particular, the article explains Nurdin Abdullah's capacity to utilize symbolic capital in order to win in the gubernatorial election of South Sulawesi in 2018. The study uses the ideas of Thomas Gibson regarding symbolic knowledge in elaborating the symbolic capital of Abdullah. In South Sulawesi, the nobility is a symbolic capital, Karaeng, that places Abdullah as an elite in the structure of society. Abdullah is well known as a Karaeng, local nobility, or traditional elite who occupies the highest position in the social structure. The predicate of nobility is a symbolic capital that was the most influential power used in gaining political contestation of the gubernatorial election. As an educated and enlightened aristocrat, Abdullah is well-aware that this symbolic capital is firmly embedded in social life, influences the dynamics of local politics, and has massive followers. Herein lays the urgency of the political aristocracy. By that, Abdullah has been successful in reproduction from symbolic capital to political power bringing him to be a Governor.
\end{abstract}

Keywords: Capacity, Nobility, Symbolic Power, Governor, Election.

\section{Introduction}

The Gubernatorial Election (Pilgub) is a race for political office [1]. Through the Pilgub, both traditional elites (aristocracy) and modern elites (educated elite) compete with each other for power. This article aims to explain the success story of Nurdin Abdullah in achieving the governor's power. The success demonstrates the capacity of Abdullah in optimizing his resource, mainly symbolic capital intelligently that is a form of personal excellence. This symbolic capital has political content that can create solidity among the aristocracy as the traditional ruling elite. Maintaining the identity of a traditional elite is an essential part of preserving the nobility and honor of the nobility. In this regard, through the Abdullah figure winning in the gubernatorial election, traditional power is brought back in local politics, South Sulawesi [2].

Abdullah is a nobleman. His grandfather, Karaeng Pawiloi, is the $33^{\text {rd }}$ Bantaeng King. In 2014, Abdullah was appointed as the $37^{\text {th }}$ Bantaeng King. Being a King is a pivotal resource in local elections. In layered South Sulawesi society, the positions of the King and the nobility are crucial because it is regarded as a role model [3]. In the leadership tradition of South Sulawesi, the role of the aristocracy is recorded in history, and it continues today through the figure of Abdullah as a Governor of the 2018-2023 periods. 
In an attempt to examine Abdullah's role and success story in gaining the governor's power, the actor's approach is used as the analytical framework. The actor-based approach referring to Dhakidae, is used to explore what roles are played and what has been captured [4]. The role is obvious, namely capitalizing symbolic capital in influencing voters. The aim is to get the most votes in the election because the candidate who gets the most votes will be the winner. That is arguably one of the logic of democracy.

The logic, of course, requires Abdullah to use its symbolic capital as a resource to get political support from people. The use of symbolic capital is a form of intelligence in understanding the weaknesses of the rivals. Three pairs of competitors do not have royal blood. Abdullah and his success team exploited this weakness by elaborating on the position and excellence of the nobility in South Sulawesi. Bakti Research in South Sulawesi concluded that the aristocracy remained in power, although it is in a different form compared with the past [5]. The nobility controls all positions in the regional government structure from the regent, members of the Local Parliament (DPRD), the bureaucracy, the sub-district head, to the village head.

Bakti's explanation is more on the collective actors of the nobility and seems not to pay attention to the efforts of individual actors to gain power. However, in the election of governors or regional heads are very actor-based. Actors are a central factor in the electoral political process. The intended actors are individuals who can be involved in political movements [6]. In practice, this individual political tendency is seen in the process of electing regional heads (governors and regents) and presidential elections [7].

Prominent historian, Sartono Kartodirjo presents three noble figures who served as regents in the Dutch era, namely Soemodilogo as the regent of Temanggung, Tjondronegoro as the regent of Lebak, and Martanega as the regent of Bandung [8]. These three regents come from nobles played a role as Dutch 'accomplices' in maintaining their power, rather than dividing their people. Nobility and power held solely devoted to them. This behavior invited people to hate the nobility. Eventually, the existence of the nobility as the ruling elite collapsed. The explanation is very different from van Klienken's findings in understanding the existence of nobility in Indonesia today. Based on van Klienken research, the Sultan has a symbolic role that can be used to gain public office or support local political leadership [9].

Those explanations have two critical notes. Firstly, the Sultan or the King is a key actor and be part of the struggle for power. This explanation is confirmed through the figure of Abdullah. Abdullah is the King who succeeded in establishing Bantaeng as the most advanced local government in public service and the high level of economic growth. Success in leading a district requires fighting for a higher position, namely the governor. Secondly, Sultan or Raja are accustomed to acting as a vote-getters in elections. The role of vote-getter is beneficial for politicians or political parties in every election. For example, the victory of the Golkar party for decades in South Sulawesi is strongly supported by the nobility.

Political openness requires aristocratic and non-aristocratic actors to compete. The nuances of competition in the Pilgub refer to French political scientist Maurice Duverger that is each individual who must fight the others to maintain his existence [10]. Struggle in the political arena in order to get the central position. In the elite theory, it has been explained that competition for power will bring out the best, the most capable, and those who are the most capable of governing. A figure that has proven their leadership always refers to the figure of a nobleman. In fact, aristocrats can mobilize formal institutions [11]. The noblemen in government have indeed been tested and proven in the trajectory of the people of South Sulawesi. This success is embedded in the hearts of the people of South Sulawesi. It can be seen in Abdullah's leadership in Bantaeng, which has brought development for Banteng [12], 
[13]. Success in governing strengthened his position as an accomplished aristocratic actor. In other words, Abdullah can combine between ascribed status (obtained) and achieved status (performance).

\section{Research Methods}

In order to understand the figure and the role of Abdullah as a politician, the method used is psychobiography. Psychobiography is personal-based, which has been used to learn the activities and career of a figure aiming to gain power [14]. The method deeply explains and elaborates on the role and strategy of Abdullah in implementing his symbolic capacity to gain power as a governor. His intelligence to make use of the symbolic capacity brought him to a governing position. Therefore, this methodology is also known as a thematic biography [15]. It is so-called because it is mainly focused on Abdullah's capability of using the symbolic capacity in governor election. The research data were collected from literature such as books, journals, and newspapers with the topic related to the research problems. And, it also involved interviews process with some lecturers, the Chairman of Regional General Election Commission (hereinafter KPUD), activists, and people with capacity and knowledge about Abdullah's capability of using his symbolic capacity to gain power.

\section{Results and Discussion}

\subsection{Symbolic Power and Local Knowledge}

People of South Sulawesi have a sufficient understanding of the activities and roles of aristocrats. The aristocrats, or commonly called Karaeng, serve as a symbol power in the perspective of Bourdieu that is shown in the form of social prestige and respect) [16]. Human beings are always thirsty for respect in many different ways. To be respected by having symbolic capacity is not easy to pursue since it takes into account origin and line of descent. Those give the highest position for aristocrats within the social scope in society, where they exist in social space, at a position shaping them as a superior and distinct individual [17]. Symbolic power is an asset owned by those with a superior position, which is used to maintain superiority in front of people [18].

Such a perspective has been commonly accepted. In South Sulawesi, aristocrats are positioned as superior while the rest is deemed as inferior, like what happens in Makassar. It is frequently told to children and grandchildren not to forget their origin. This is intended to distinguish between those in lower social class and those in superiority without having to violate the power of the superior. This has been an example among people of Makassar, where understanding someone's position is essential [19]. Local understanding of the essence of symbolic power is always brought by aristocrats in order to strengthen their existence in a social structure [20].

Both Cummings and Putra argue that those having symbolic power can continue leadership. As an individual with a high position, an aristocrat is distinguished from other people. This understanding is firmly rooted in society. Moreover, the local perspective sees aristocrats as a gift from a goddess where power is given to run leadership as an authority that is sacred and absolute [21]. Such a perspective legitimates the status of aristocrats as local 
leaders. This understanding is backed up by the result of the dialogue between Sam Ratulangi and Lanto Daeng Pasewang. Once Sam Ratulangi raised a question: who is the most influential person in the social life of South Sulawesi? Lanto Daeng Pasewang clearly stated that it was aristocrats who were the most influential in the social life in South Sulawesi [22].

\subsection{Symbolic Power and Social Status}

Karaeng is the symbolic power for the people of South Sulawesi, where three social strata are hierarchically known as Karaeng, Daeng, and Ata. This social stratification explains their position or rank, which emphasize not only their position but also their respectability in their social circle. Karaeng is placed on top of the pyramid, where it has fewer numbers compared to daeng and ata. Despite its few numbers, it still holds a significant position. Sulistyo argues that karaeng is superior and has dignity positioned in the highest social rank [23]. Those accepting defeats are seen as ones having no dignity, like ate community. Apart from superiority, there have always been substantial social gaps separating the aristocrats and ordinary people [24].

However, those gaps have benefitted the aristocrats in terms of hierarchical relationships [18], where the aristocrats have access to politics and economics. In terms of governor election, for example, power in both politics and economics is taken into account in addition to symbolic capacity. Political capacity is required to gain support from political parties that have the authority to propose a candidate, while economic capacity is needed to finance campaigns, adverts and to run the structure of political parties and political supporters.

The control over political, economic, and symbolic capacities placed Abdullah as a complete figure in candidacy to gain power by becoming a governor since three parties supported him: PKS, PAN, and PDIP. The economic capacity, however, is linked to the fact that Abdullah is a successful businessman with national and international business networks, including Japan. His symbolic capacity is what is defined as karaeng and Raja Bantaeng (the King of Bantaeng). As a karaeng and Raja (a King), his network connected to the community of Keraton Nusantara (national kingdom) is broad, and such a symbolic capacity is not owned by Nurdin Halid, Agus Arifin Nu'mang, and Ichsan Yasin Limpo as candidates (see Table 1).

Table 1. Social Status of Paired Candidates for Governor

\begin{tabular}{|c|c|c|c|}
\hline \multirow{2}{*}{ No } & \multirow{2}{*}{ Name } & \multicolumn{2}{|c|}{ Social Status } \\
\hline & & Aristocrat & Non-aristocrat \\
\hline 1 & Nurdin Halid and Abdul Azis & & $\sqrt{ }$ \\
\hline 2 & Agus A Nu'mang and Taribali L & & $\sqrt{ }$ \\
\hline 3 & Nurdin Abdullah and A. Sudirman S & $\sqrt{ }$ & \\
\hline 4 & Ichsan Yasin L and A. Muzakkar & & $\sqrt{ }$ \\
\hline
\end{tabular}

In Table 1, it shows superiority for Abdullah as he holds symbolic capacity that allows connection to other aristocrats in South Sulawesi. Abdullah was backed up by the community in Bulukumba in which Karaeng Tomo gave support to Abdullah in governor election (Monitor, 13/6/2018). Harian Fajar (4/3/2018) informed that the aristocratic families of Abdullah kept giving their support to win the election. The influence given by aristocrats contributed to the victory of Abdullah (in an interview with Rahmat Muhammad, 15/11/2018). Thus, it explains that the solidity of aristocrats gives the member of their community a way to winning governmental positions for elites. Cooperation and capacity to mobilize people in the 
election have dated back to the past among aristocrats up to these days; such a system is still needed to give Abdullah access to become a governor of South Sulawesi.

\subsection{Karaeng as a Traditional Elite}

Karaeng is a traditional elite, and this argument was embarked on from the classic work of Fred Von Der Mehden. For Mehden, the traditional elite consists of religious leaders, aristocrats, and landlords with their privilege [25]. Besides, aristocrats can also serve as landlords, as most of the aristocrats in some areas such as Yogyakarta, Maluku, Jeneponto, and Bantaeng. Owning lands indicates there is a practice of feudalism. It is clear, as Mehden has argued, that aristocrats and their relatives have broad areas of land.

Ownership of land is a source of power among aristocrats. Lands have economic and political roles, where economically lands owned by aristocrats can feed people and aristocratic families themselves. Those having such a resource are considered as patron [3], while politically, the cultivation of lands by local people leads to a patron-client relationship. This relationship shows imbalance, either economically or politically. This imbalance indicates that elites have more power over people [26]. Such an unfair situation is always maintained, and the intention seems to position traditional elites on top of power.

\subsection{Karaeng as Instrument for Mobilization}

In the gubernatorial election, the peerage of Karaeng had been used as an instrument for mobilization. This occurred because firstly, Karaeng that holds symbolic power is useful to mobilize people to take part in the governor election. The task of Abdullah is to figure out how to run the symbolic capacity to gain support for his candidacy in governor election. Karaeng is known to have plenty of lands that allow people to work on the lands and, therefore, the lands provide the livelihood for the people. People benefitting from this land provision are expected to show their reciprocity of giving political support, so are their families. This condition is seen as a chance by Abdullah, who decided to embrace aristocrats to be part of their political supporting team.

Secondly, Abdullah has followers who work for his company or followers of People from Bantaeng, expected to give him their support in governor election. Syah Cangara and Sultan asserted that the people of Bantaeng expected him to be a governor of South Sulawesi [13], and the rank of aristocracy is indicated by a huge number of followers [23].

Thirdly, as a King of Bantaeng with a significant position in Keraton Nusantara, Abdullah quickly built more networks with other aristocrats in South Sulawesi, where the networks serve as fundamentals to form social solidarity and raise the rank of aristocracy higher, leading to broader access to becoming a governor. Abdullah may be seen as hope among aristocrats. Networks in the circle of aristocrats were built, which was mainly aimed to give political support to Abdullah, meaning that the aristocrats acted rationally for common interest [18].

Fourthly, Abdullah has his capacity to embrace aristocrats in either government or nongovernment positions. This capacity comes from the fact that Abdullah has aristocratic blood and is educated. "We vote for Abdullah since he is an aristocrat, a professor, and we hope to be ruled by an educated aristocrat," KPUD Bantaeng said (in an interview conducted on 10/10/2018). This line has strengthened the morality of a symbol that is attached to Abdullah. His aristocracy and his professor's title were simply a selling point for him in his candidacy for governor election. 
This seems that Abdullah had even the strongest position between the other two candidates who only earned their master's degree. This symbol of intelligence is even more apparent in a tagline: 'Professor Andalan' (professor of the central figure). Such a person with such a central figure shows that Abdullah was far more excellent than his rivals in politics. This excellence spread structurally, systematically, and massively in several mass media and social media.

Fifthly, the leading figure as the candidate is far more important than the political party that brings the candidate to the forefront. In a percentage, seventy percent of influence is given by political figure, while the rest $30 \%$ is from a political party. These days, political parties lack the flexibility to mobilize the organization at the social level. Therefore, the candidate built his pathway to victory (in an interview with Sahajuddin, 23/10/2018). Abdullah is an influential figure and is widely welcomed with open arms by people in South Sulawesi. Abdullah is a well-known figure since he was capable of transforming Bantaeng from poor and unpopular state to a developed state with several destinations to offer (in an interview with Aldi Sido, 13/10/2018). The ability to bring such a transformation is considered as an added value to strengthen his position in candidacy since none of his rivals had capacities comparable to Abdullah's.

\subsection{Gaining Power as a Governor}

The symbolic capacity owned by Abdullah has brought him to the governing position of South Sulawesi. His capability to gain power in the election back in 2018 was an achievement in the history of governor election. Firstly, the victory of Abdullah in the election can be said as the victory for aristocrats in South Sulawesi. Abdullah, as a governor, managed to lift the respectability of the aristocrats higher. For fifteen years, aristocrats had been out of power, where none was involved in leading positions. They were only to witness daeng holding power. Syahrul Yasin Limpo was a daeng making his way to the ruling governor for two serving periods.

Secondly, the victory of Abdullah as a governor indicates there was a sense of defeat faced by national elites at the local level. It has been commonly known that central elites in Jakarta are often described as powerful actors with wider networks connecting all types of societies. Nurdin Halid, Abdul Azis, and Tanribali Lamo are renowned among people and have been in the political world for more than ten years and have been renowned in South Sulawesi. Nurdin Halid represented the Golkar Party, Abdul Azis, a member of Regional Representative Council and a son of Qahar Muzdakka. At the same time, Tanribali Lamo was a soldier holding a critical post in the Ministry of Home Affairs, and he once served as a task executor for a governor of South Sulawesi. With all his career, experiences, and networks, so it is without a doubt that Tanribali's popularity is further higher than Abdullah's. This fact could be traced down from research finding Poltracking on 18-25 May 2017, as shown in Table 2.

Table 2. The popularity of Candidates in Governor Election

\begin{tabular}{|c|l|c|}
\hline No & \multicolumn{1}{|c|}{ Candidate's Name } & Percentage \\
\hline 1 & Nurdin Halid & 48 \\
\hline 2 & Agus A Nu'mang & 55 \\
\hline 3 & Nurdin Abdullah & 42 \\
\hline 4 & Ichsan Yasin Limpo & 57 \\
\hline
\end{tabular}

From Table 2, it is clear that the top position was held by Ichsan Yasin Limpo, representing 57\%, followed by Agus A Nu'mang 55\%, and the lowest accounted for $42 \%$ for 
Abdullah. The popularity shown is actually not proportional to the ballot of Governor Election. The recapitulation of KPUD of the Province of South Sulawesi positioned Abdullah as the winner, as shown in Table 3.

Table 3. Abdullah's Winning Votes

\begin{tabular}{|c|l|c|c|}
\hline No & \multicolumn{1}{|c|}{ Candidate's Name } & Total & Percentage \\
\hline 1 & Nurdin Halid and Abdul Azis & 1.261 .751 & 26,65 \\
\hline 2 & Agus A Nu'mang and Tanribali Lamo & 419.005 & 10,91 \\
\hline 3 & Nurdin Abdullah and A. Sudirman S & 1.867 .303 & 44,41 \\
\hline 4 & Ichsan Yasin L and A. Muzakkar & 809.330 & 18,02 \\
\hline \multicolumn{2}{|r}{ Source: KPUD South Sulawesi, 2018. } \\
\hline
\end{tabular}

The number of votes won by Abdullah at $44.41 \%$ indicates the resilient level of aristocrats against central elites. Nurdin Halid and his pair projected to win only gained $26.65 \%$ of votes, although he accepted the defeat and admitted the capacity of Abdullah. It shows that aristocrats were more welcomed than non-aristocrats in governor election. The victory of the aristocrats was more because of their capability of attracting more support from people.

Thirdly, the victory gained by Abdullah has given a lesson implying that an incumbent represented by the candidate Agus Arifin Nu'mang (having served as a vice for Syahrul Yasin Limpo) could not guarantee a victory in governor election. Of the four candidates, Agus Arif Nu'mang had the fewest votes, accounting for only $10.91 \%$. This number means that for the ten-year serving period, he had limited space under the leading position of Syahrul Yasin Limpo to do more for his people (in an interview with Syamsuddin, 2/10/2018).

Finally, Abdullah and his vice, A Sudirman Sulaiman, were representatives of aristocrats from Makassar and Bugis, respectively, and this mixture is seen ideal for the governor election. Therefore, the winning moment for Abdullah also represents the victory for the aristocrats of South Sulawesi. Politically, this victory is also taken as a defeat of senior politician that has been active in politics at the national level (an interview with Herpina, 27/9/2018) and also taken as the defeat among aristocrats. The victory by the aristocrats also means the defeat of non-aristocrats. This phenomenon indicates that the circulation of elites took place where power rules.

\section{Conclusion}

In the Gubernatorial election, all candidates certainly require symbolic power, especially in terms of the culture of the people of South Sulawesi that are hierarchical and in strata. Peerage of Karaeng for the people of Makassar and the title Andi among people of Bugis represents the symbol of social status and honor that show distinction serving as the basis of local knowledge accepted through generations. In other words, peerage is a social status that influences every phase of social life, ranging from marriage to political activities.

In the competition to gain governor position, Abdullah comes from an aristocratic background and the Kingdom of Bantaeng, and he has politically benefitted the peerage to build networks among kings and other aristocrats all over South Sulawesi. The aristocratic and king position makes a symbolic power to be mechanical solidarity from other counterparts to show their identity as a governing elite. Therefore, due to his intelligence in using his symbolic power in the governor election has brought Abdullah to victory. This victory has brought back the aristocrats to formal governing structure, which is seen as a political 
achievement that has to be recorded in history. Moreover, this victory also indicates that an aristocratic actor is superior to non-aristocrats.

Therefore, the status held by Abdullah as primus interpares (the best above all) is deemed relevant. The governor election putting the capacity of an actor to the forefront for power actually profits aristocrats. This is essential to know that in a direct election, aristocrats are far more ready to compete than senior politicians and non-aristocrats. This phenomenon indicates that the circulation of elites took place where power rules.

\section{References}

[1] C. Lay, "Blok politik kesejahteraan: merebut kembali demokrasi," Samadhi, W., PolGov, 2016.

[2] T. Gibson, Kekuasaa: Raja, Syeikh, dan Ambtenar. Makassar: Ininnawa, 2009.

[3] Suhartono, Beberapa Catatan: Patron-Klien di Sulawesi Selatan. Yogyakarta, 2007.

[4] D. Dhakidae, Menerjang badai kekuasaan: meneropong tokoh-tokoh dari sang demonstran, Soe Hok Gie, sampai putra sang fajar, Bung Karno. Penerbit Buku Kompas, 2015.

[5] A. F. Bakti, "Kekuasaan Keluarga di Wajo, Sulawesi Selatan, dalam Henk Schulte Nordholt," Polit. Lokal di Indones. Jakarta KITLV Jakarta dan Yayasan Obor Indones., vol. 491505, 2007.

[6] A. Savirani and O. Tornquist, "Reclaiming The State.” Jogjakarta: Polgov dan PCD, 2016.

[7] W. P. Samadhi, Blok politik kesejahteraan: merebut kembali demokrasi. PolGov, 2016.

[8] S. Kartodirjo, "Berkembang dan Runtuhnya Aristokrasi Tradisional Jawa'," in Kepemimpinan Jawa: Perintah Halus, Pemerintahan Otoriter, H. Antlov and S. Cederroth, Eds. Jakarta: Yayasan Obor Indonesia, 2001.

[9] G. Van Klinken, "Return of the sultans: the communitarian turn in local politics," in The Revival of Tradition in Indonesian Politics, Routledge, 2007, pp. 169-189.

[10] M. Duverger, Sosiologi Politik. Jakarta: Rajawali Pers, 2003.

[11] Pratikno, "Bila Kecamatan sebagai Basis Pengembangan Intermediari," Transform, vol. 1, no. 2, 2004.

[12] Z. Tamimi, "Inovasi Manajemen Pelayanan Publik Tim Emergency Service Kabupaten Bantaeng," Polit. J. Ilmu Polit., vol. 6, no. 1, pp. 141-158, 2015.

[13] D. Syah, H. Cangara, and M. I. Sultan, "Opini dan Sikap Masyarakat terhadap Pembaharuan dan Kepemimpinan Bupati Nurdin Abdullah dalam Memajukan Bantaeng sebagai Kota Industri dan Wisata," KAREBA J. Ilmu Komun., vol. 4, no. 3, pp. 300-314, 2016.

[14] M. Mas'oed, "Studi Hubungan Internasional: Tingkat Analisis dan Teorisasi," Univ. Gadjah Mada, 1989.

[15] S. Kartodirjo, "Metode Penggunaan Bahan Dokumen," in Metode-Metode Penelitian Masyarakat, Koentjaraningrat, Ed. Jakarta: Gramedia Pustaka Utama, 1986.

[16] R. Jenkins, "Membaca Pikiran Pierre Bourdieu," Yogyakarta: Kreasi Wacana, 2004.

[17] G. Ritzer and D. J. Goodman, Teori Sosiologi Modern. Jakarta: Kencana, 2011.

[18] J. Field, Modal sosial. Yogyakarta: Kreasi Wacana, 2003.

[19] W. P. Cummings, Penciptaan sejarah Makassar di awal era modern. Penerbit Ombak, 2015.

[20] H. S. A. Putra, "Konteks Sosial-Budaya Demokrasi di Sulsel'," 2014.

[21] Mattulada, "Demokrasi dan Tradisi Masyarakat Indonesia," Prism, 1977.

[22] H. Abdullah, "Feodalisme Dan Revolusi 1945 Di Sulawesi Selatan," 1989.

[23] B. Sulistyo, "Konflik, Kontrak Sosial, dan Pertumbuhan Kerajaan-kerajaan Islam di Sulawesi Selatan," SOSIOHUMANIKA, vol. 7, no. 1, 2014.

[24] W. F. Wertheim, M. Z. Ellizabet, and A. F. Husein, Masyarakat Indonesia dalam transisi: Studi perubahan sosial. Tiara Wacana Yogya, 1999.

[25] F. Von Der Mehden, Politik Negara Berkembang. Jakarta: Bina Aksara, 1987.

[26] T. B. Bottomore, "Elite dan Masyarakat,” Jakarta Akbar Tanjung Inst., 2006. 